九 是

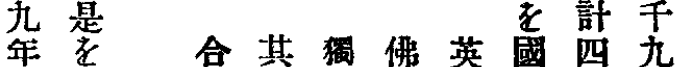

の手計浪他國國國别古百

四父國口势杂

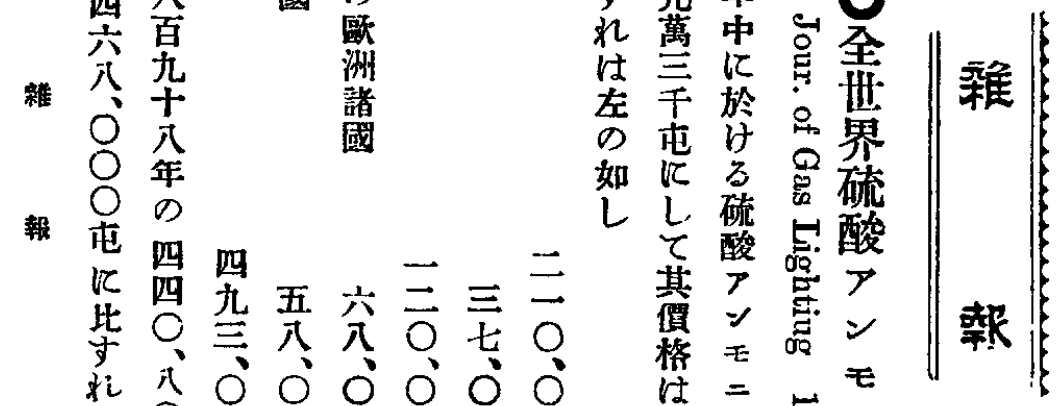

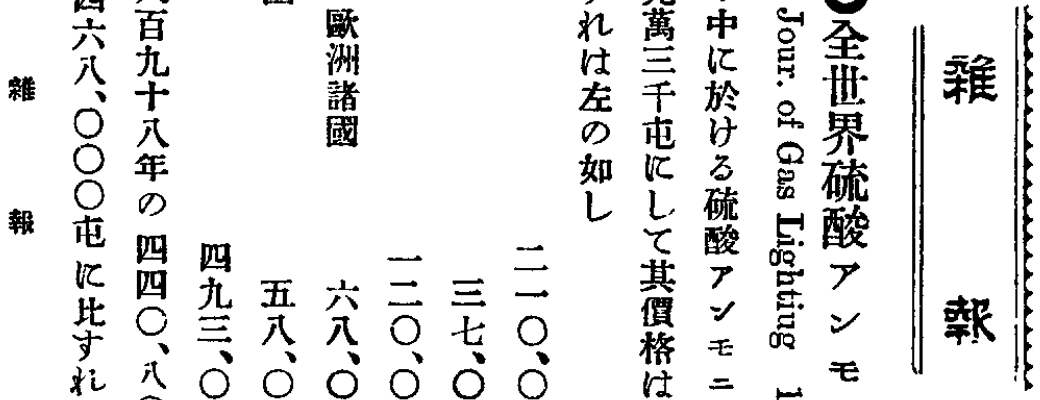

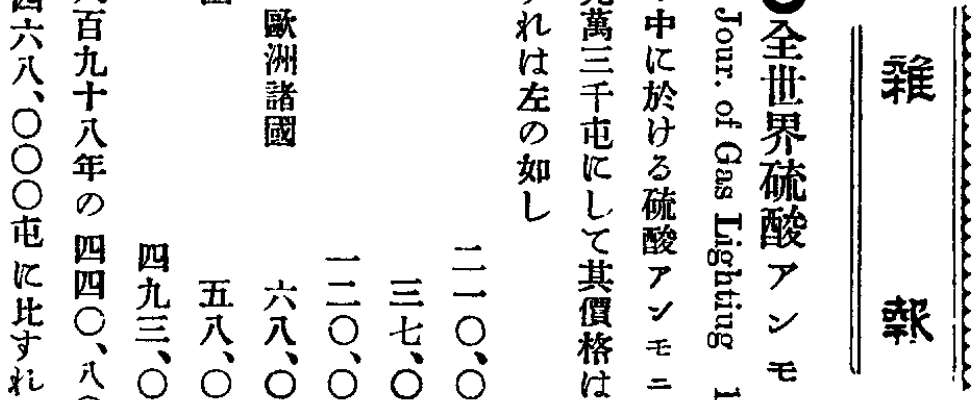

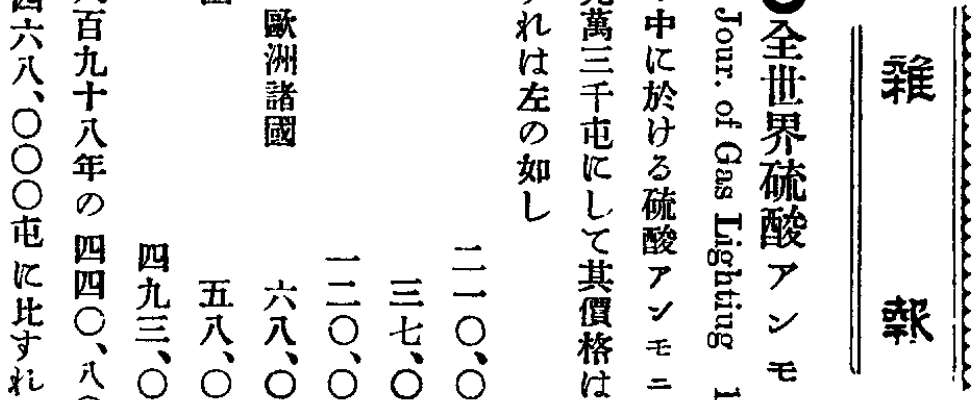

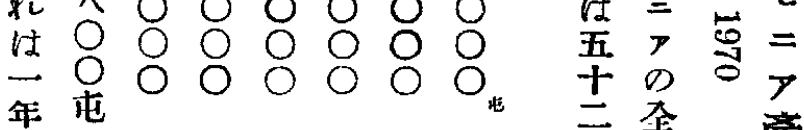

平 又

均一

約 入

吾百

五赸產

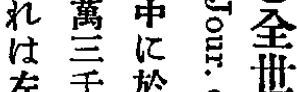

席斿

如 《要

界

界 額

极產

$b$ 額

社

位十

額 總

四

問

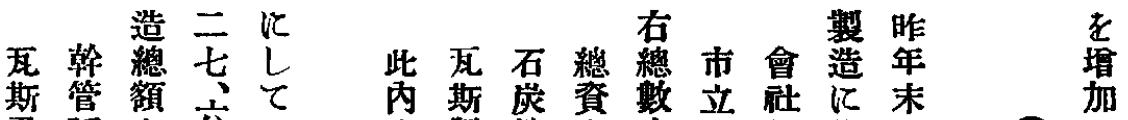

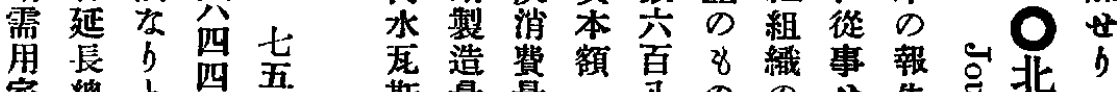
家總之四五斯量量分のの告

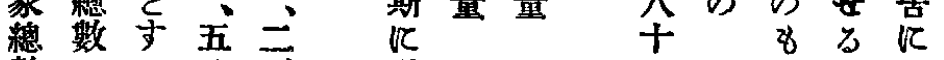
數 分芜要

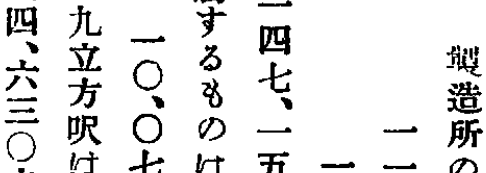

の过合茾

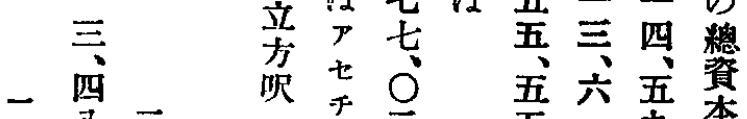

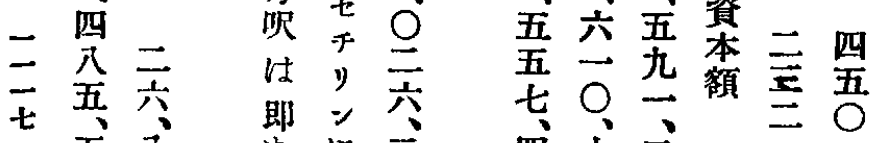

五八

古 $k$

四六三

五 0 石屬一元一

七七厐儿 0 二

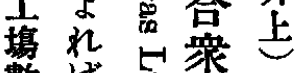

戶哩

虚竞

斯方

立电£

數芯点國

製一吹吹

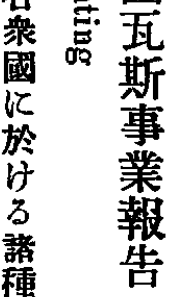

の

经

用

互

斯 
日

本

r

於

日引日讨

万各本老約代

杏本見五死

愿江方\% 斯

筫些於心需整

签焉放し角造

軷家角

高客并は石

は高不上約宛

近㤩原

著署䈯

著票筫

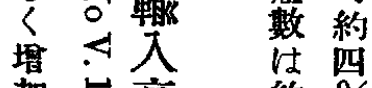

加灾高

\%
約 \%

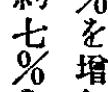
安加

発家高需

死无

用 慗 整

造 角

炭
現死杖 あ工右

報斯立り场の街

告製に文数他燈

之造て㡷は總

九事士加會油數

年紫三水村: 不

前の无の油

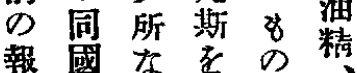

辣 塟
よ紐 亡一のて

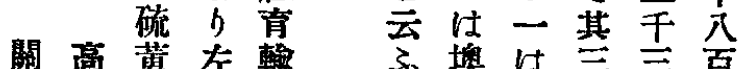

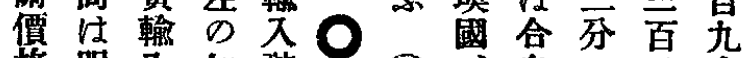

格明入如硫紐并佛㳟の元十

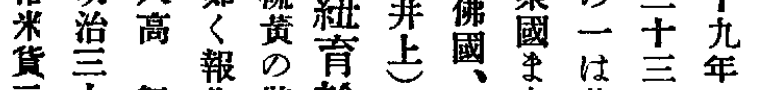

三干既告 鼎輸

百年往劣规

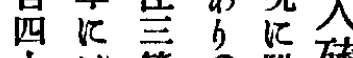

十壮简尔附硫

吗士年浆き黄

吾吾於賞同金

千公け

四乎当

百 賞

三百國

十四軩

弗士 入

同六碩黄

主此甬

十通 總
白 英五に

耳棸咸杂於

義六及手け

分其百方

角二領七全

國餘地十世

等㤌上七界

小獾

b乙供乞虔

虚國給

\# b 5 ”額

七姴让”性

8 餘他出總

田

定

定
ののの毕䛲

小六至飞七 b分永儿镱
千千千

分八

百百百

九 九 九

十+

九公

年 年 年

용

界

5. 宸

离

豆

农額

六六一

五.九四

八呬三

公公严

一五八

九九 六

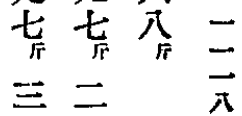

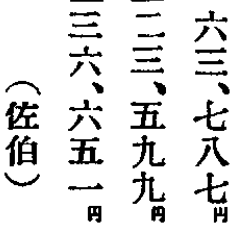


其て百品太留

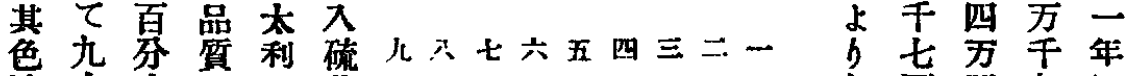

淡十中汒演

黄九知、五

雜毫以十る》品

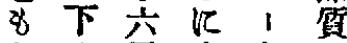

土の分由島

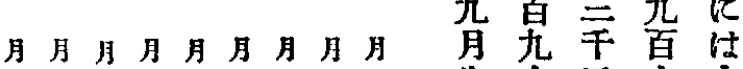

色社な重當

報をの九を虐藏

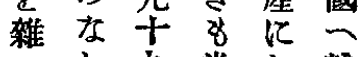

一七九當し骾

寸との罭て

之云純心其 好

公硫輸産 5

反 $h$ 莣入 $九$ 㵋十獺

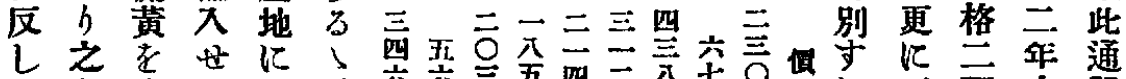

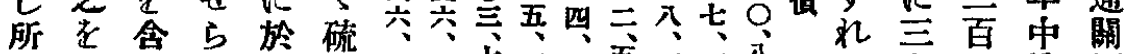

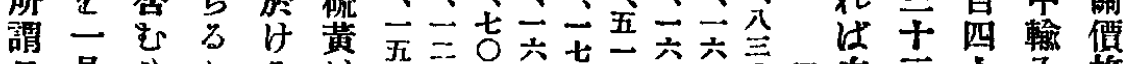

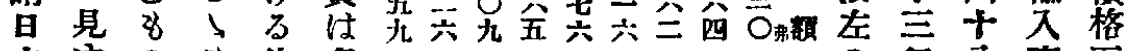

本亦の 8 他多

虐るたの嵒く

硫にしはの俶

の年公高晋

如 $\rightarrow$ 万洦

乙月四十分

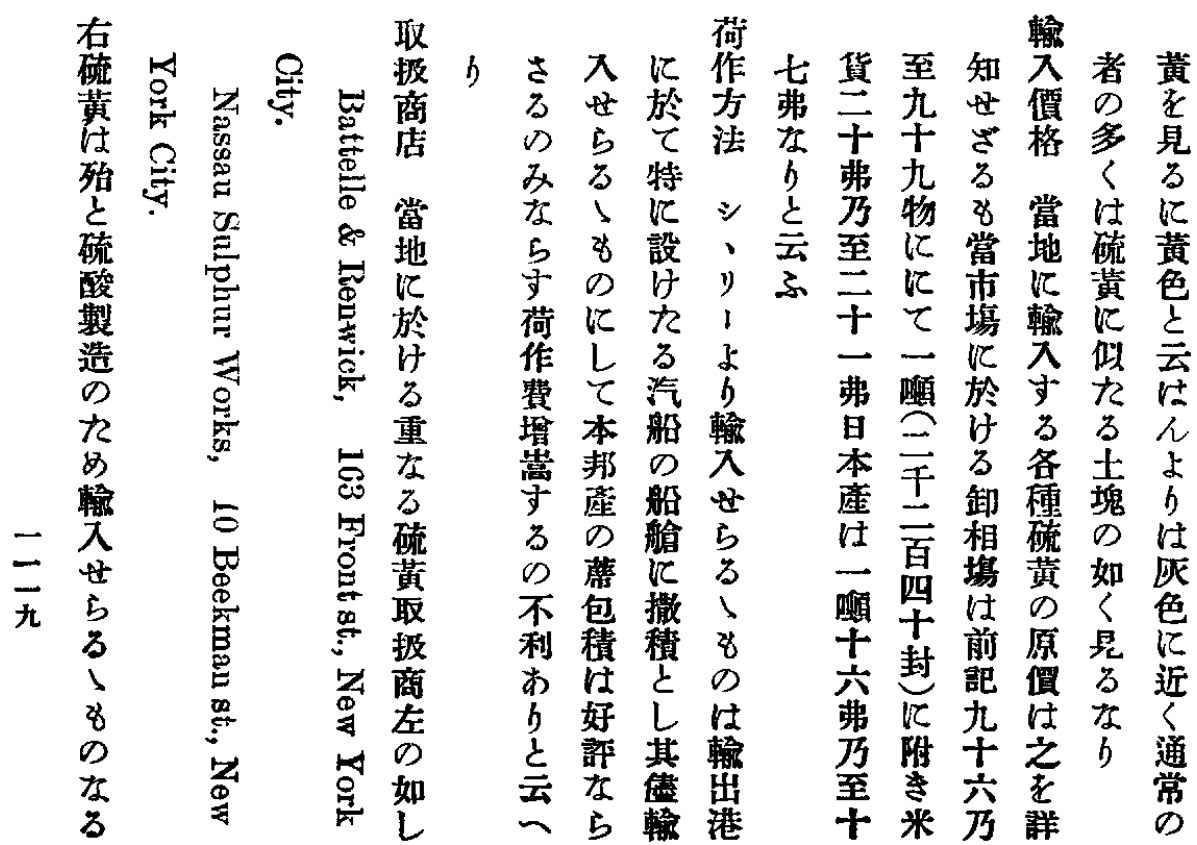


第

五省化前

條有 於 項

第守て

一る原於

項 酒容

中精量酒

酒容貧粆

精竟分方

老量串稳

削主梨

有 万

寸杜

る攝石超清石梁

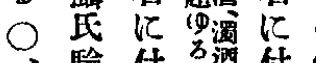

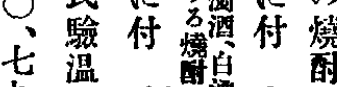

九器に酒㳑金

四豁金精

七五它分

の 度吾度

比の铔

重 特
第 第 酒

制 四一造之てか

第 第第合條條选云硫近

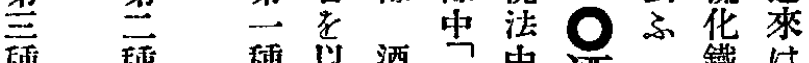

酒類酒左酒浩其

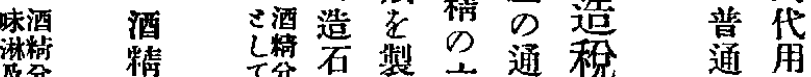

分筫分石製六通税

製二稅些程改法百物

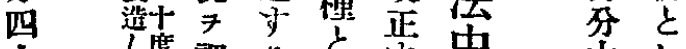

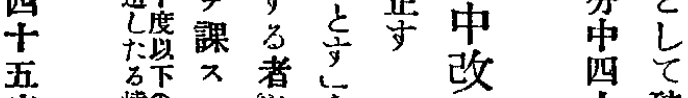

十硫

其吾 法 老鐵

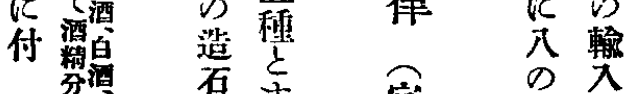

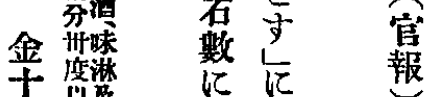

純少

硫 加

黄 占

考

含 而

U L

前飞製た第 犯第 $九$ 造第 の物切す第

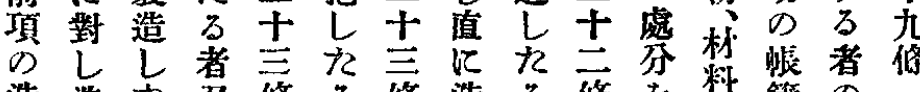

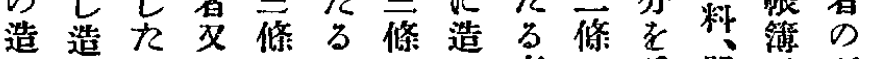

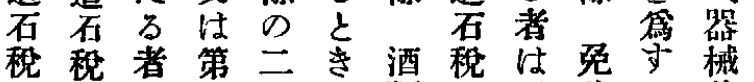

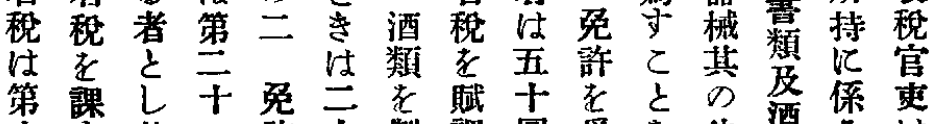

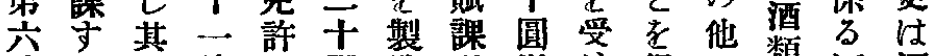

條分條者造微以得只類酒酒

の 製の受员世收上立

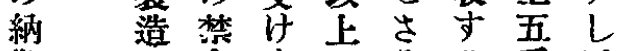

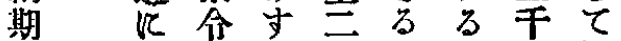

飞俰学し百者乙圆酒

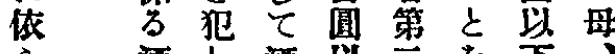

ら酒し酒占云索

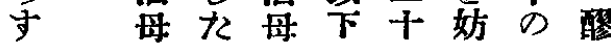

直、る、の一け罯又

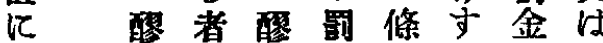

之融金の酒

老穆淘製它䄷處類

納石酒造處命

U

數老し守学

致

物製酒酒

件 造 教

及其製

檢はの造

綮眅 製守

し賣 造 る

文出者

は必入及

監 要には

督应關之得場

上るす老

ᄂ 合

K $k$

改於 


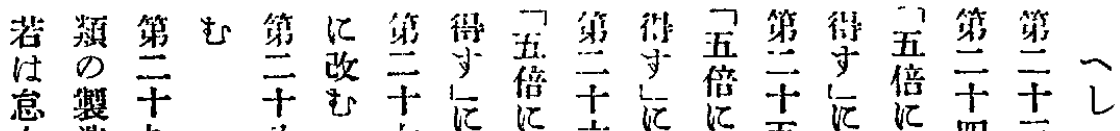

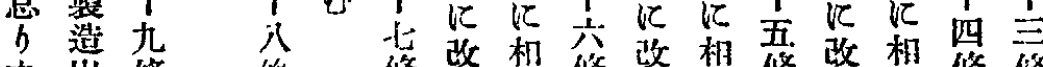

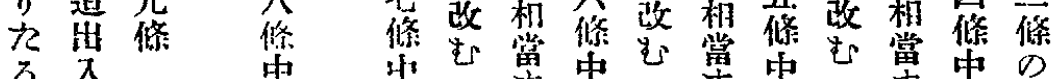

粣 3 入

簢数

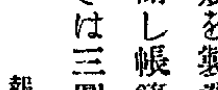

報

韯者

十又又

圈壮壮

证事之

F實齐

の 贿

羁申頡

金告等

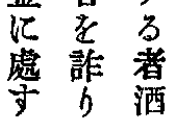

圆 鯂 造

以の守

上訅 号

中

Fi +

圆

案

$+$

娄?

㑊

吾

面

窟

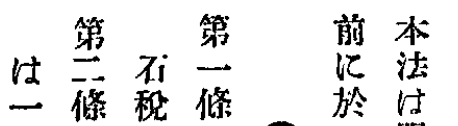

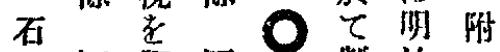

江酒諳酒

付精守精酒成焉则

原及精亡千

容在酒及办叫

意酒精酒分年

筸精酒酒十

分を含精類月

中含舍飞一

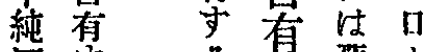

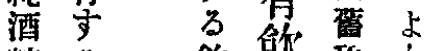

精了飲飲程

二合飲料萃之

三容料秷を地

三量老杜涗適施

慜本法惩行

筬造 法 寸寸

每

几名依鼠

金 ह

七

造
但

日
专贵

罚

金江

飞相

虔賞

但总

算

南息

圆科

站 料

学点

老家
כ

壾 倍

金江

飞相

丕賞

寸

但总

望

十吪

署科

繁

气虔

年
号

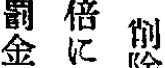

相除

豦堂

但哥

产䓔

面箱

敢粘

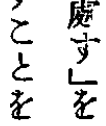




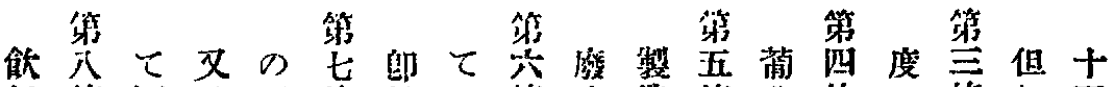

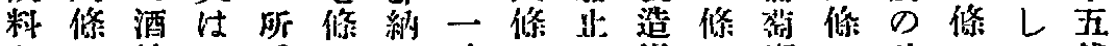

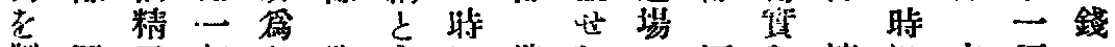

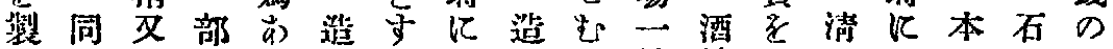

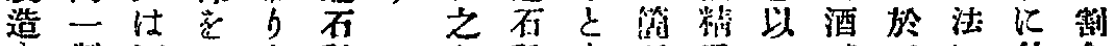

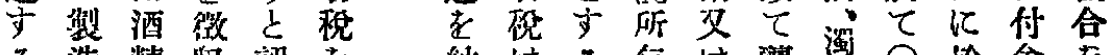

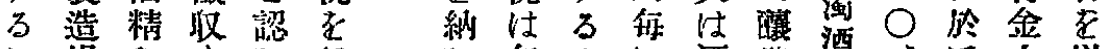

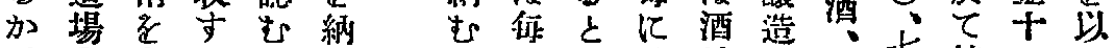

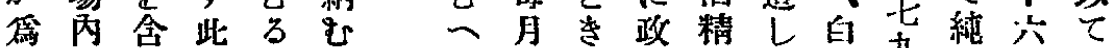

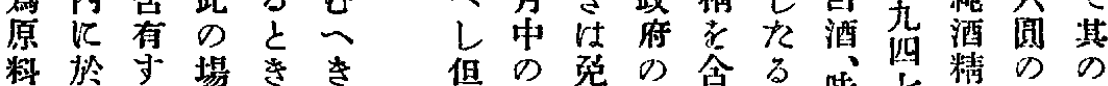

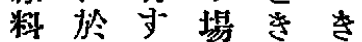
とてる合は诸 L 酒 领 $儿$ 政 邆 乙 精 料 於 府 石 使文艺杜税 朋江差は直を 酒抑納に逋 る 精京稅 造 脱 酒をるの石せ 精含乙擔 税 む 又有亡保》亡 は老主全 酒る得し郚る

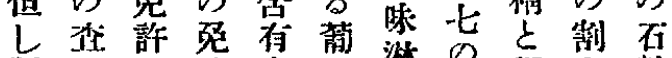

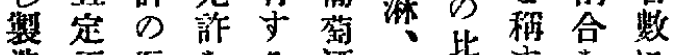

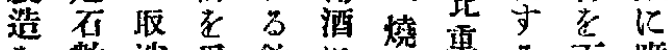

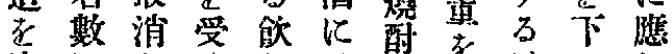

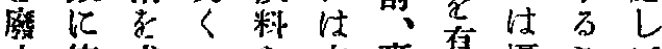

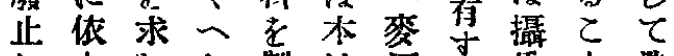

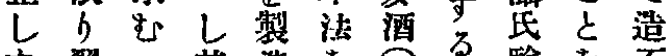

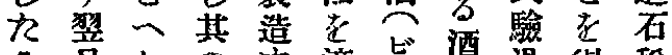

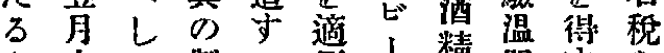

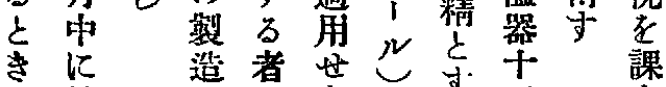

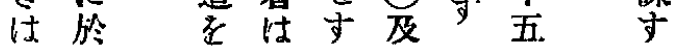

三二一定寸第飞は犯寸し成第人は前精

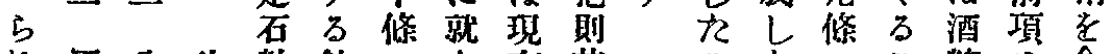

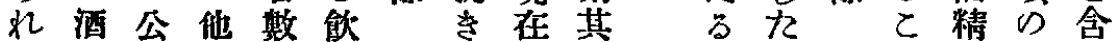
九精䝿人之料第製のの酒る製とを規有

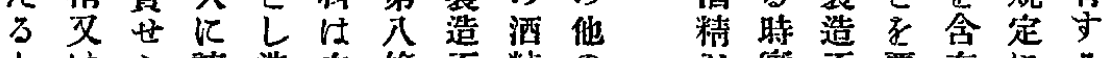
之社讓造在條石精の留石要有飞る

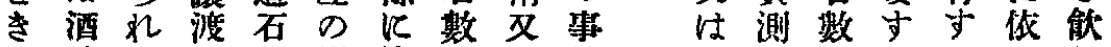

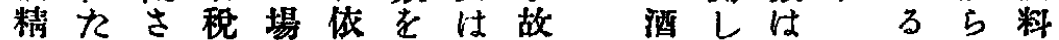

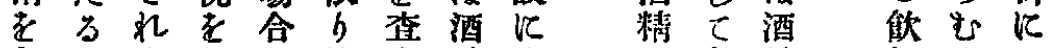
舍と九課飞检定精传を之精料文性

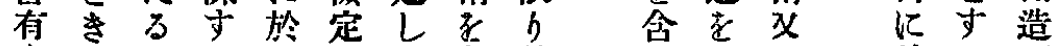

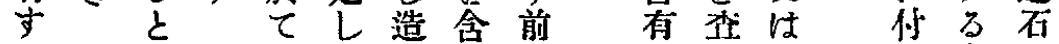

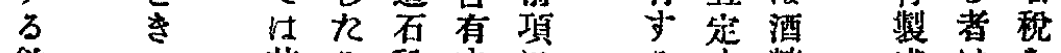

飲

犊

製

造

牌

外

江

消

費

$甘$
其る稅守代

の酒老方依

憸精課飲 b

定文于料難

石惊

數 酒

精

以

$\tau$ 含

省有
若意

愓

證 合

㜻 に

物於

件
万守精

能但齐

料 ᄂ 舍

性前省

此條守

力江

限传领

的料

在检

占管製
維

越 


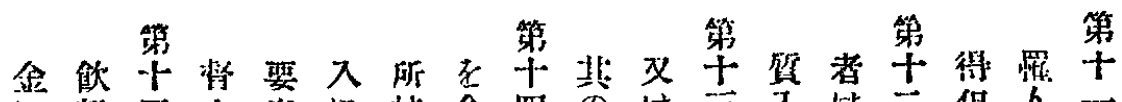

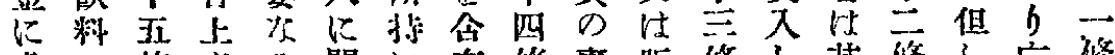

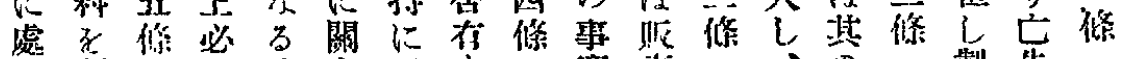

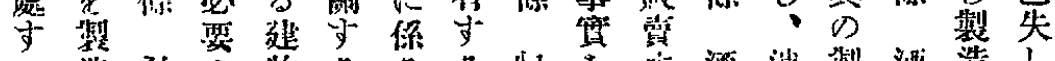

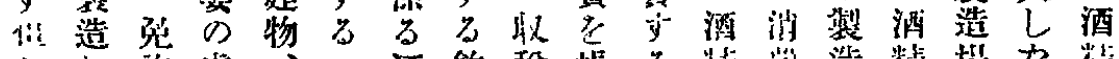

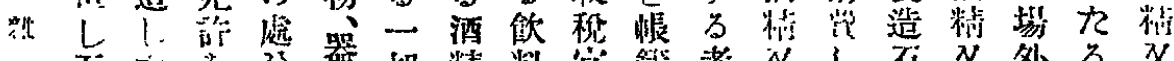

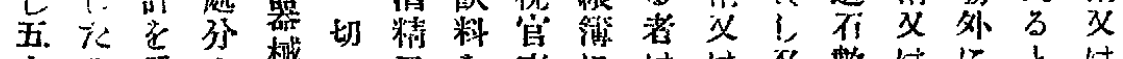

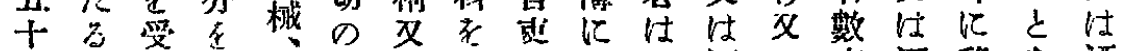

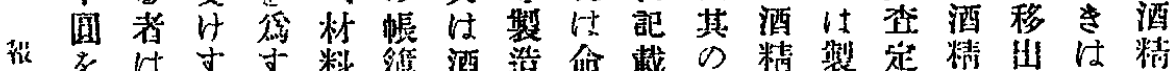

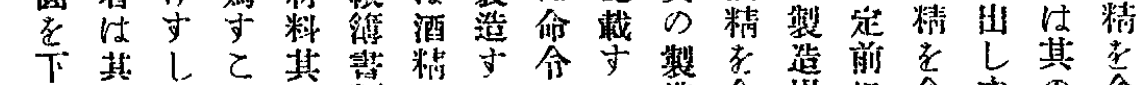

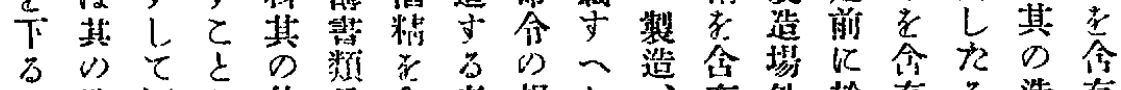

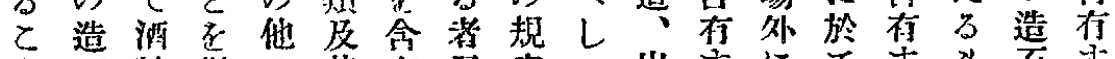

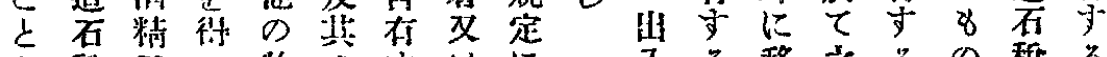

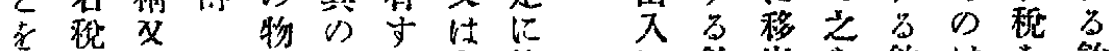

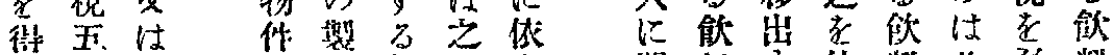

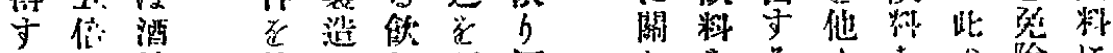

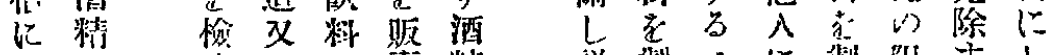

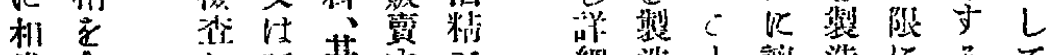

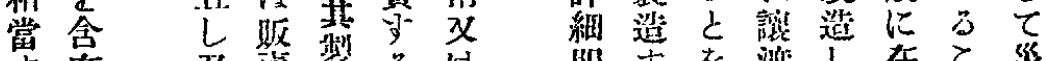

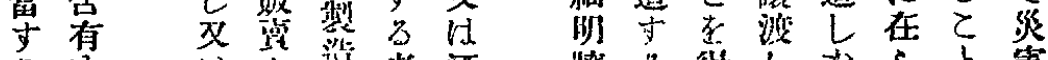

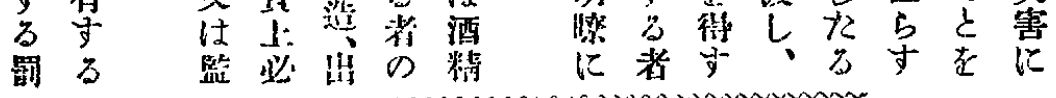

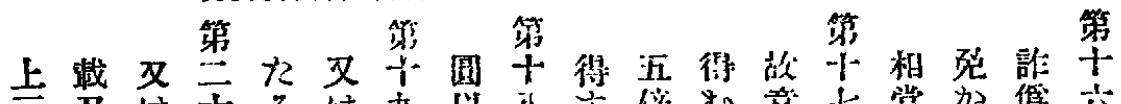

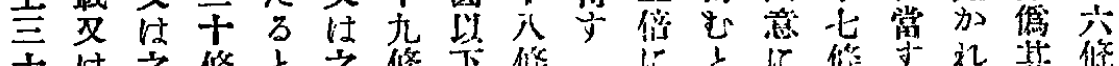

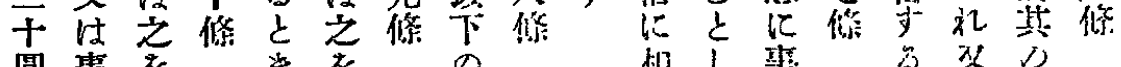

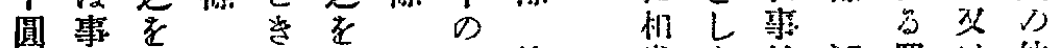

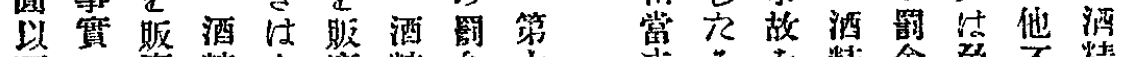

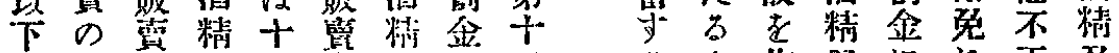

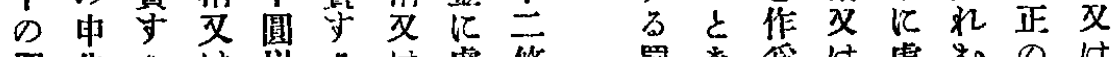

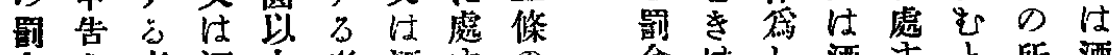
金を者酒上都酒守の企忙し酒守之所酒

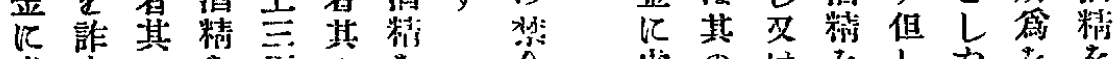

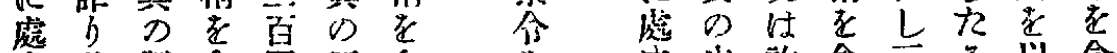

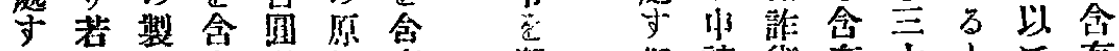
は造有以料行犯声術有市と否

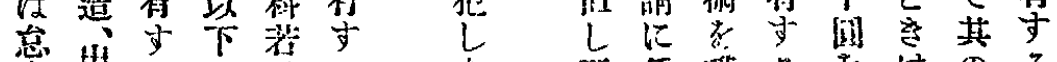

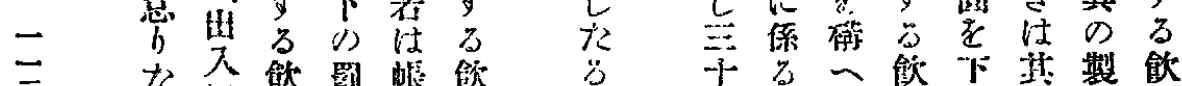

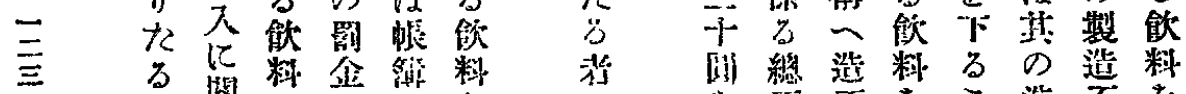

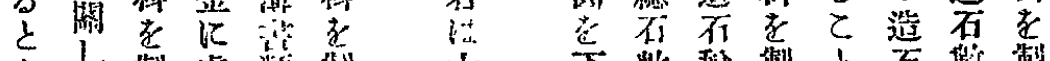

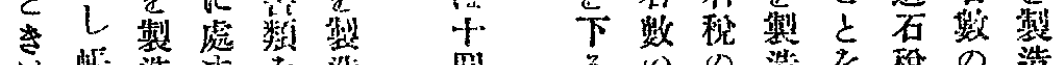

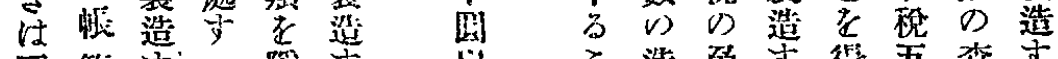

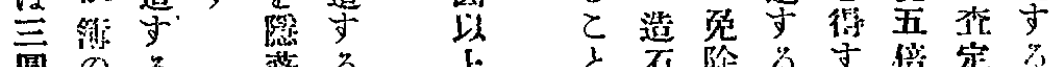

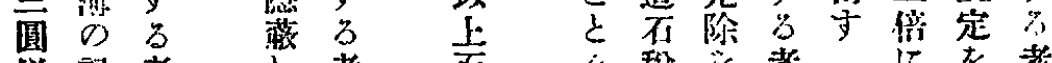

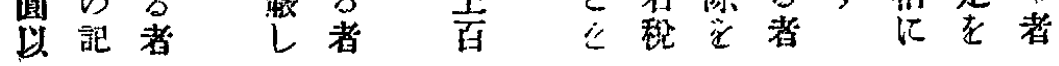


第 は止第の浆す第五整第

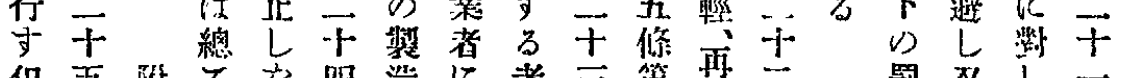

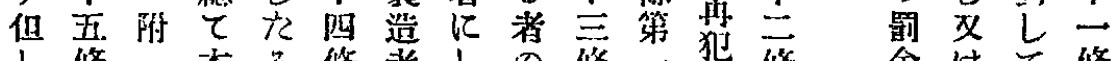

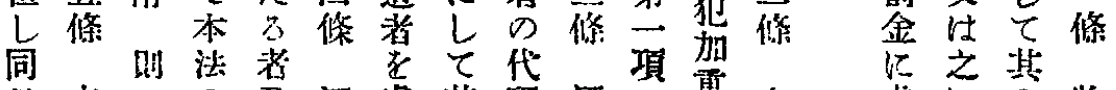
日本の及酒處其理酒の重水源汇方收䊒 前法规ひ精鲉の人精場數法方執税

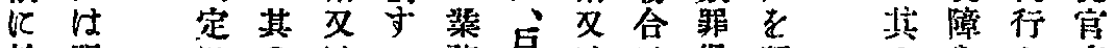

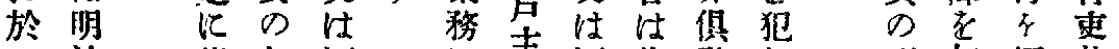
治從机酒飞弆酒此發 $L$ 刑加拒其 製三ふ鼣精關家精のの九法いみの

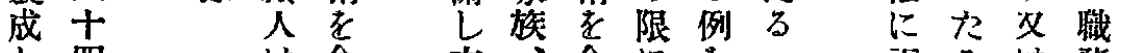

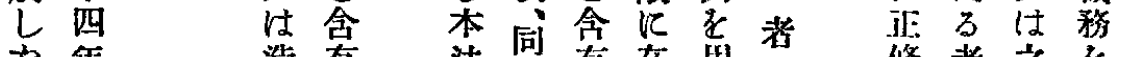

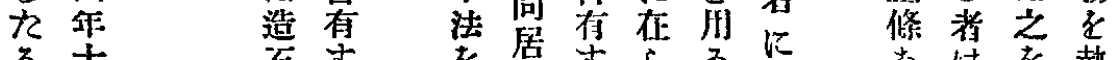

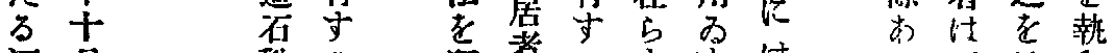
酒月梲方犯者方导は卞志行

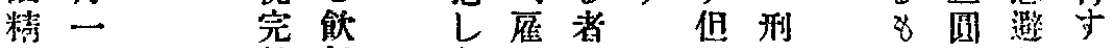

に 納 料 存人成 しの 注よ

落 $b$ 前 $D$ 其は刑不 率老

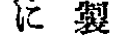

施 在 浩 と市法論 他第罪

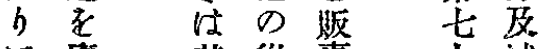
D 以 L 万 は土及る 刑恝性 法干之常

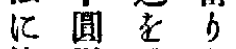
七魔共從賣十減依区总之

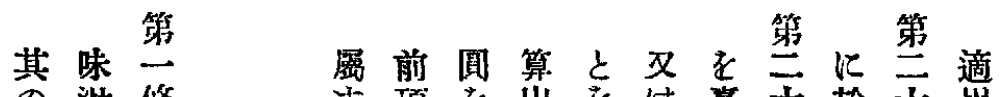

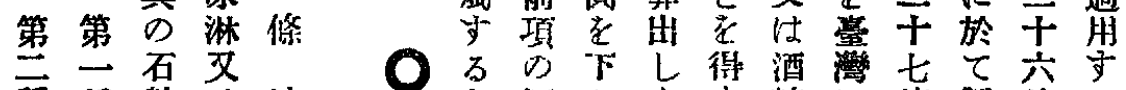
二石 及 種種 數注沖 燒 白清應㷪 繩

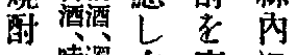
味湢左帝江 湘酒克國於 割丙

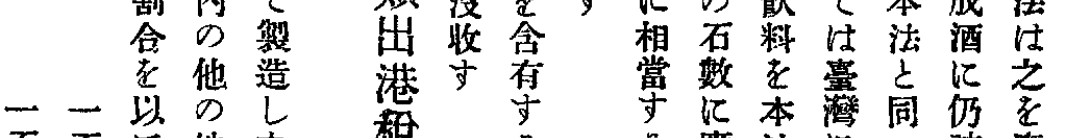

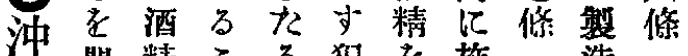

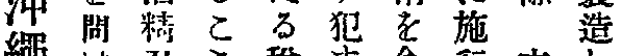

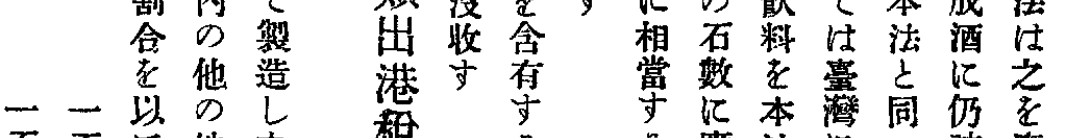

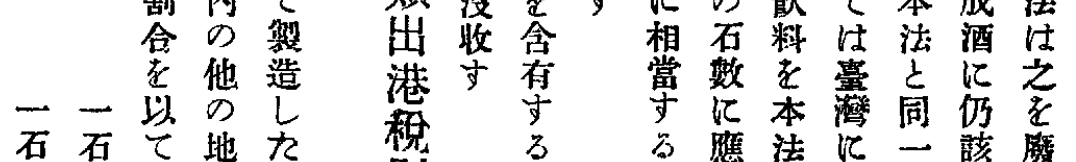

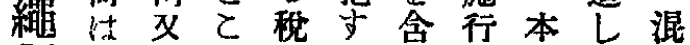

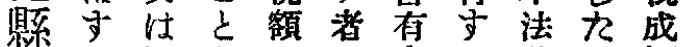
酒之酒要五生寸尚若含酒 類要精待倍其方生混税

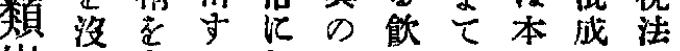

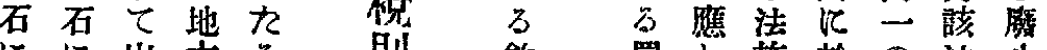
にに出方々則领罒し施於の法步 付付港公清中料金第行宁税应守

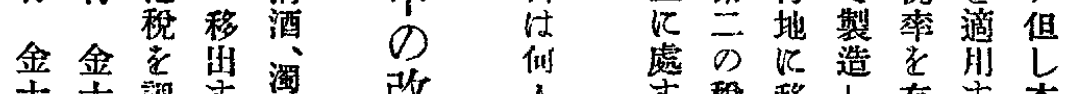

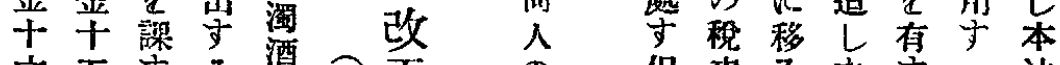

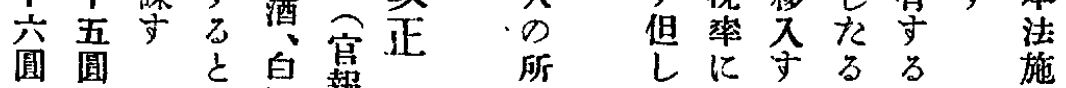
圆圆泉腺 存五往方酒法行 に十它精規前 


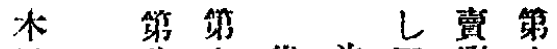

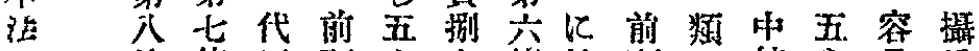

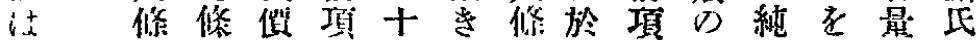

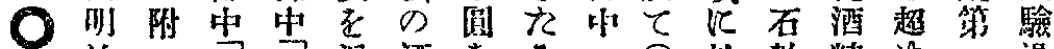
籼酒治 叫三五温酒索る

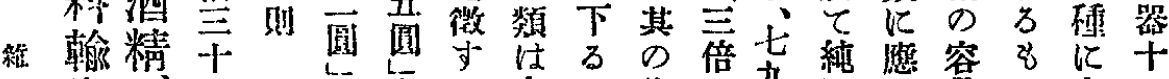

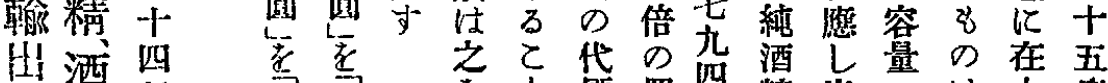

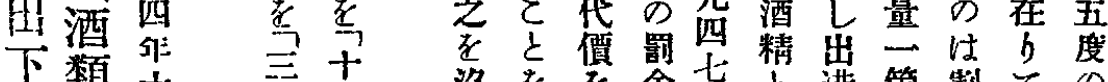

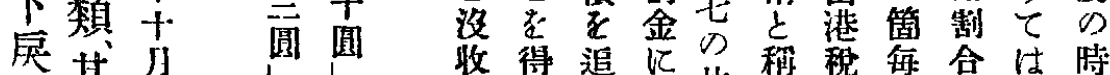

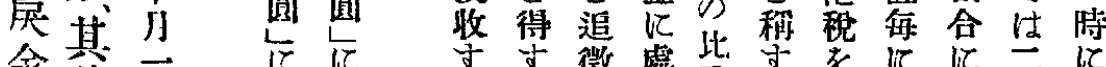

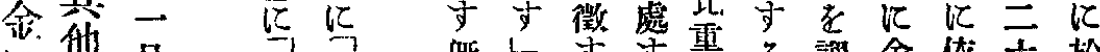

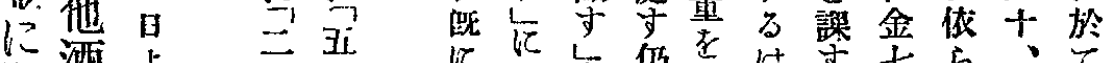

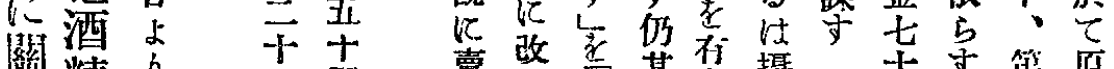

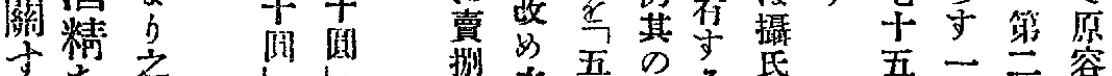

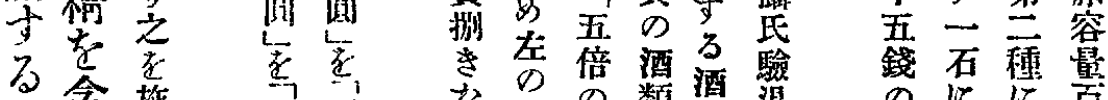

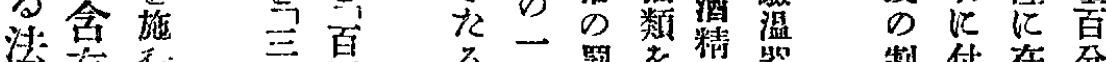

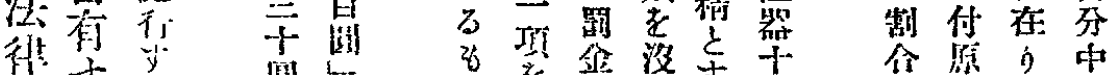

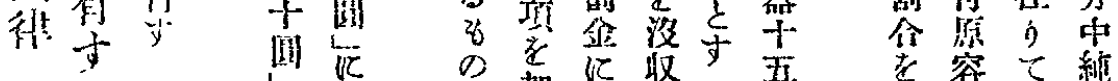

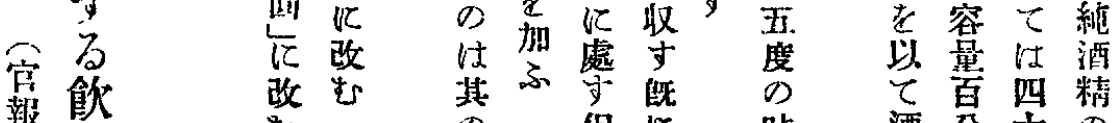

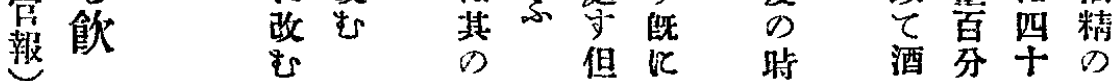

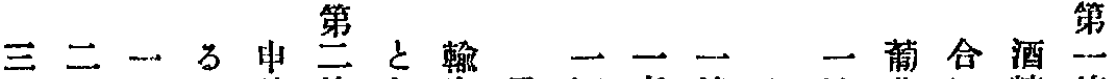
乙請條を出及酒麥燒九清蕉に精條

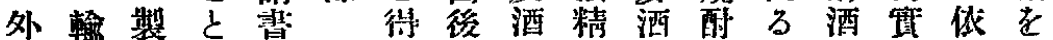

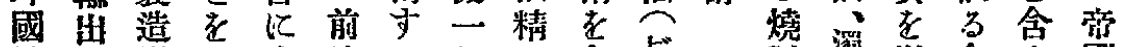
輸免場要左條年含

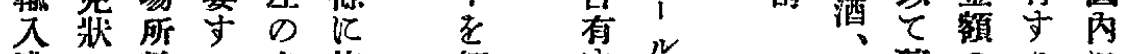
港轄畫依經一守光百共のるに

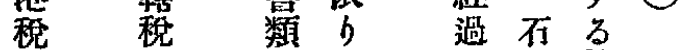

關務等金 Lに飭

の 箬 添額 叴付料

輸 の 附 の る精原に

入 交 L下主葟 $\mathrm{L}$

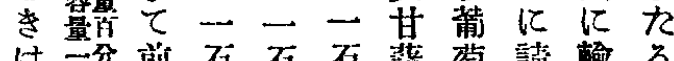

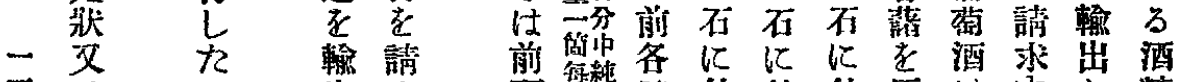

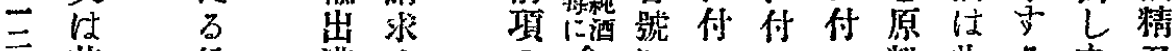

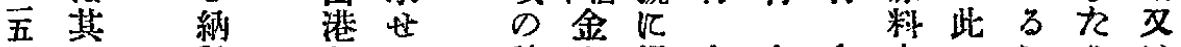
の稅税を請七揭金金金とのとるは

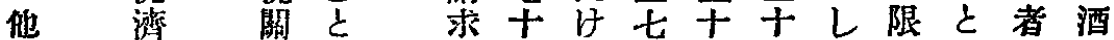
外澄に市を五さ圆六五てにをは類 國明提 万雼錢\%圆圆製在得左其 K 㳻出者守名造占但のの

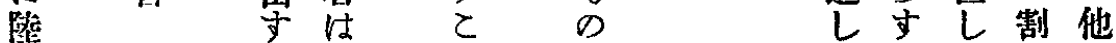




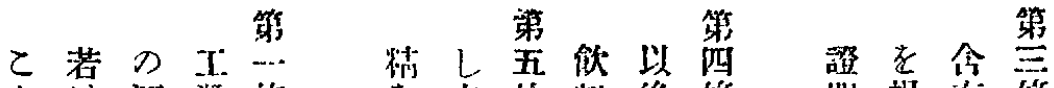

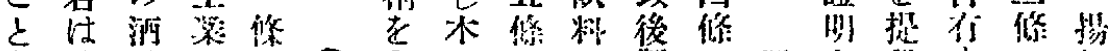

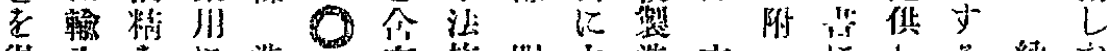

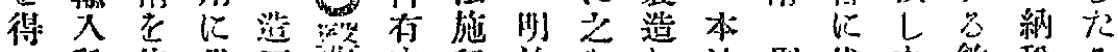

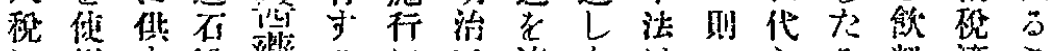

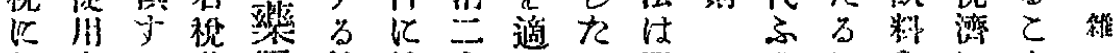

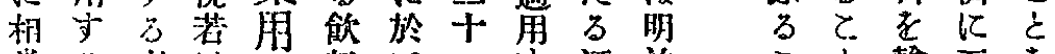

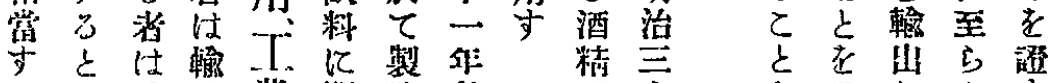

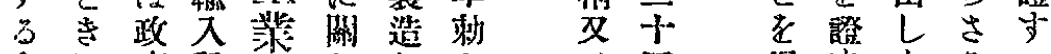

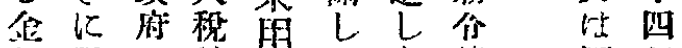

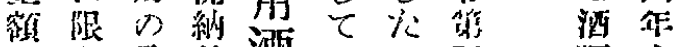

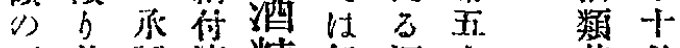

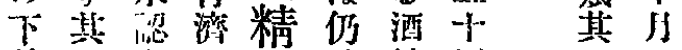

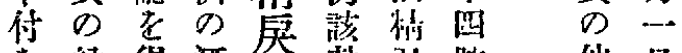

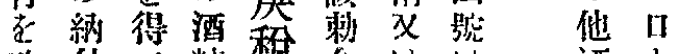
政付七粘梲合は酒上

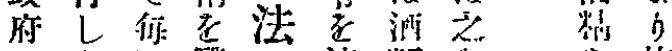

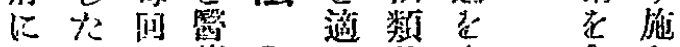

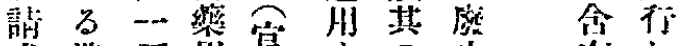

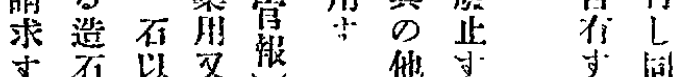

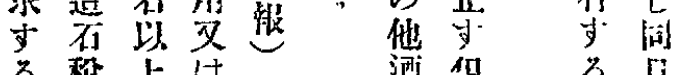
得卞九る一 几ち酒き 老教精落 涉江及数 数 梲 杜 考教 酒 以. K 数 乙 悱 其 筮當の 候里他 测 3 酒

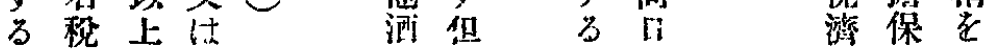
第籍 な 第

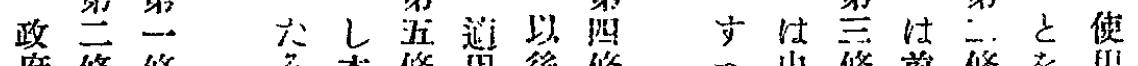

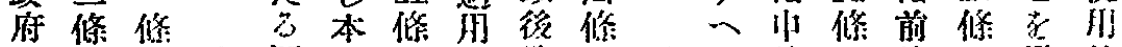

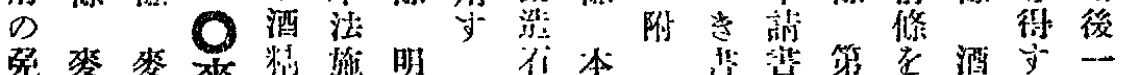

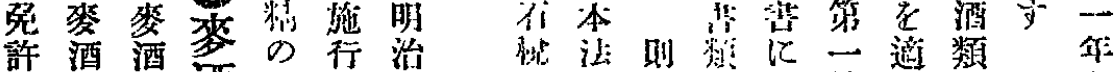

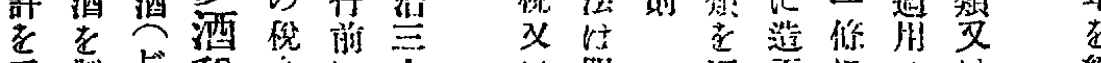

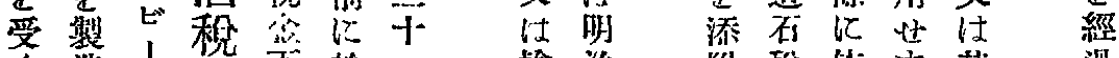

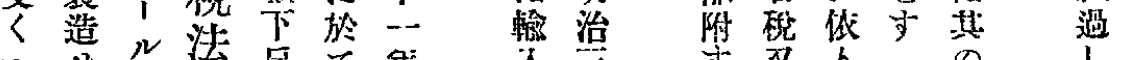

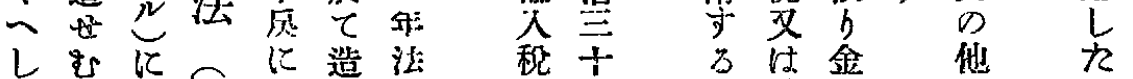

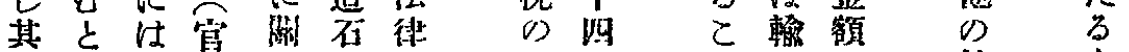

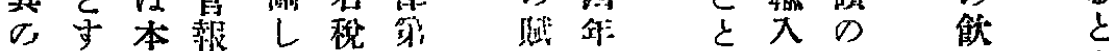

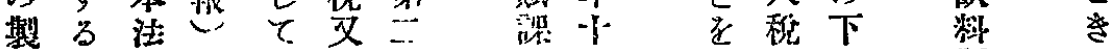

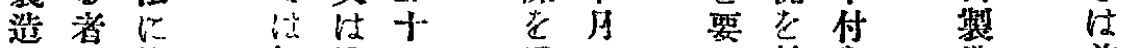
疗依仍翰 磨製

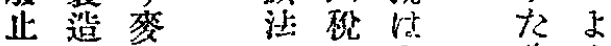

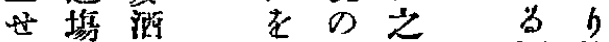

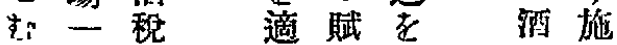

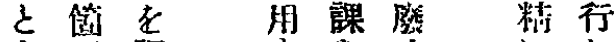

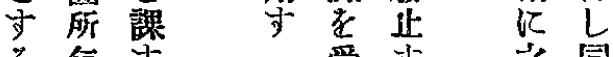

万铮等受过光同 你 請 L 求 H] 方世供 万生求 と告当蓜 と $に$

保

名档

登者江 赫 


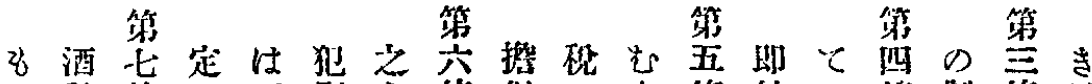

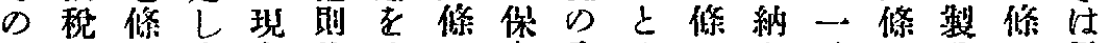

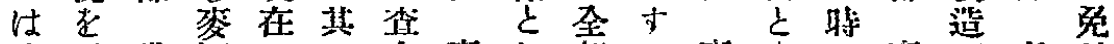

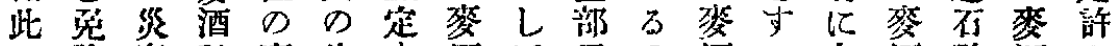

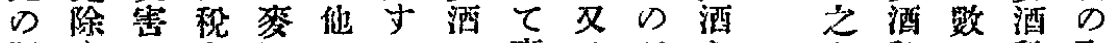

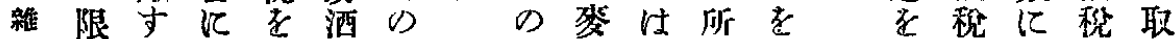

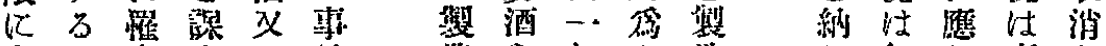

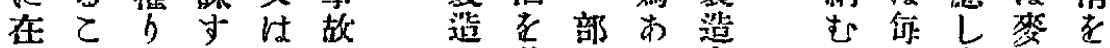

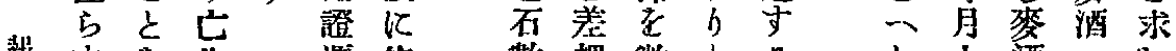

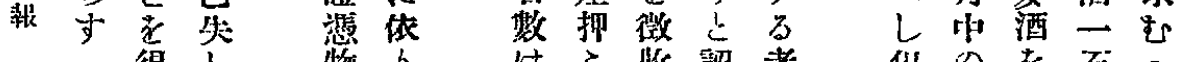
得し 物 $九$ は $心$ 收認者 但た件前製る主导麥 Lる $る$ 项成乙此方酒

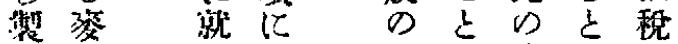
造酒を依時老算学を 場江其 $b$ 容得合江䢏

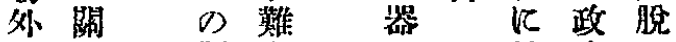
に L 整 党

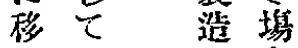

山は石全

其 数

ॠ党

於

の 於府 L

容元的

箖

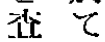

量值㨁

飞䋺に述

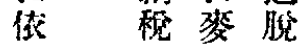

价の石へ

し敉にし

製定造付

造石少金

致了七

魔飞渚圆

政依尘

Lb h 制

九翌之合

当在暴

$\varepsilon$ 中微以

红收

将於主其

しれ以第るの第は必㸪者第践の算にの笋

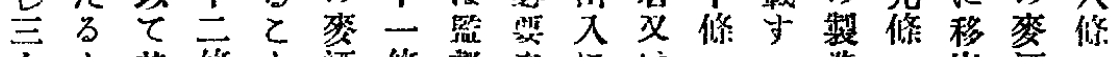
干 期修

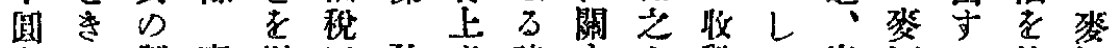

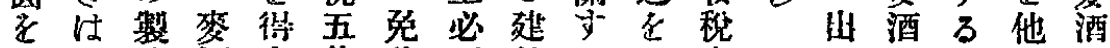

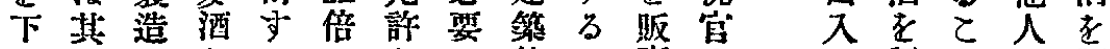

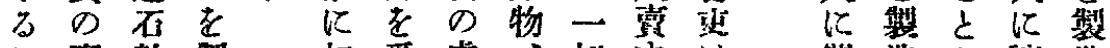

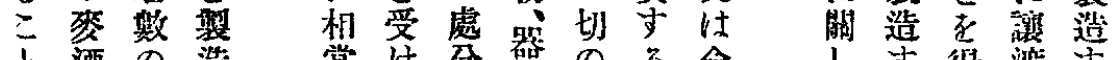

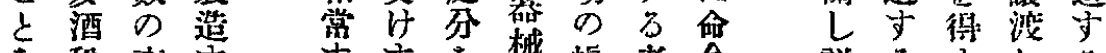

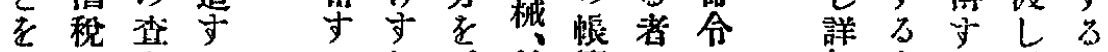

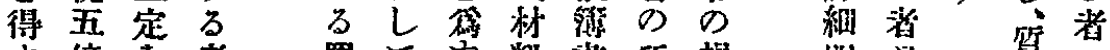
与倍老則てす料者所規 治誰金麥乙其㘤持定

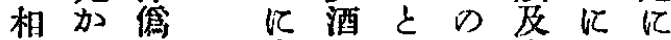

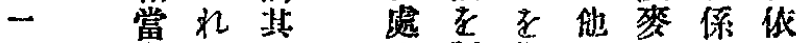

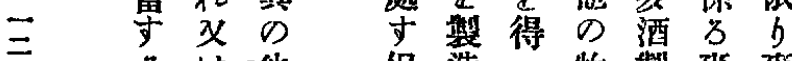

疻・他但造物製愁零

畏据不 L L 件造酒酒

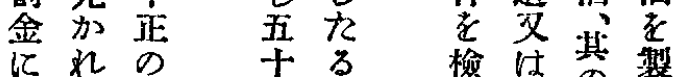

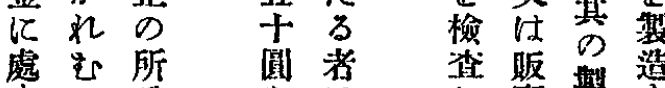

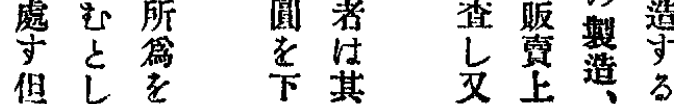

证了 又

暸注

に党

其

○肘

事. 蛽

零

学

帳 者

籍 洁

飞来

部 酒
貸者

製

、造

溜 石

費 數

L桀

视

は前

整

造於

外其 


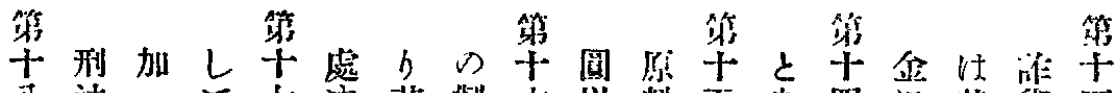

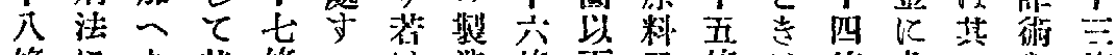

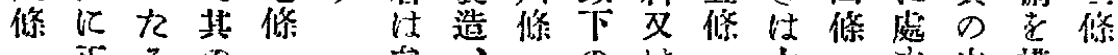
IE 200 点

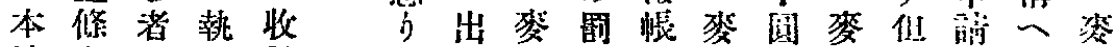

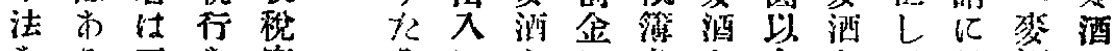

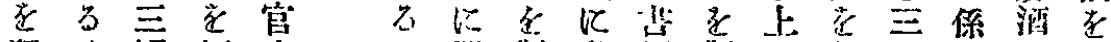

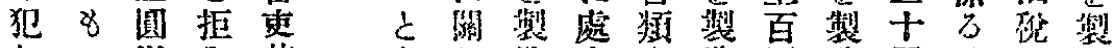

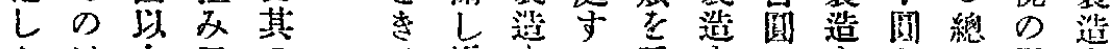

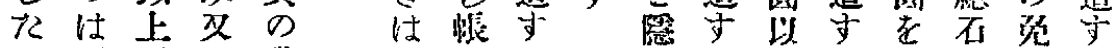

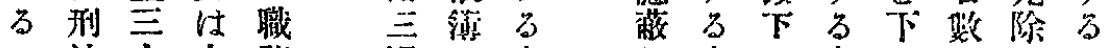

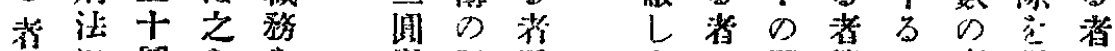

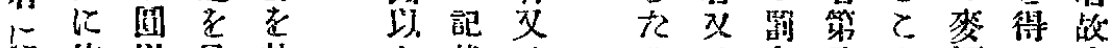

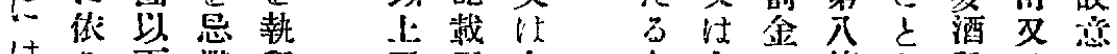

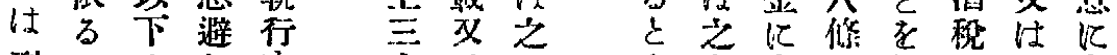

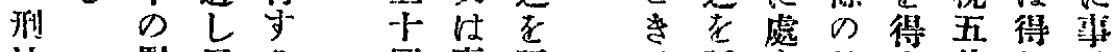

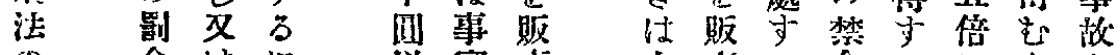

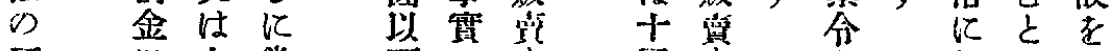

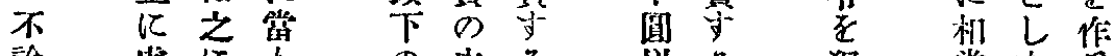

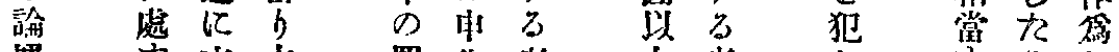

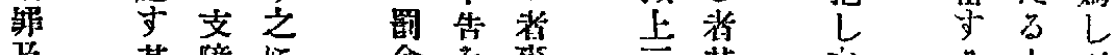

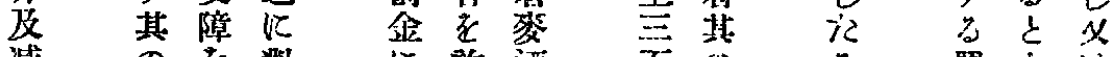

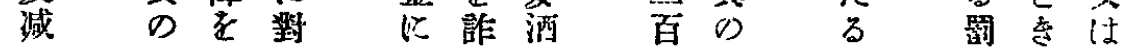

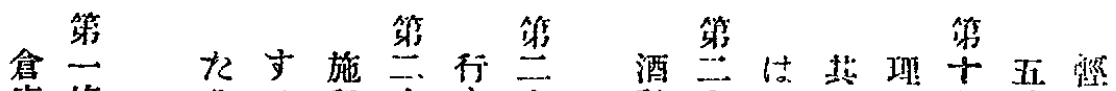

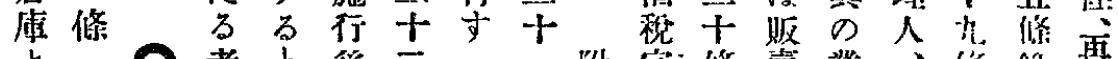

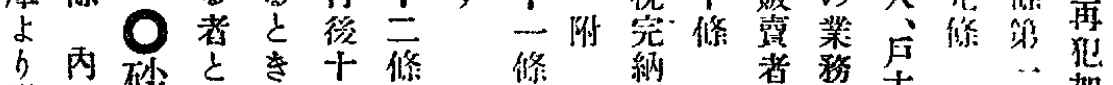

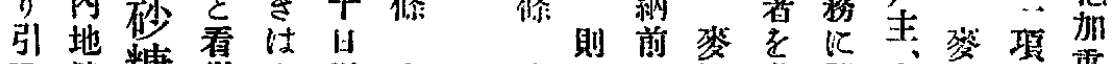

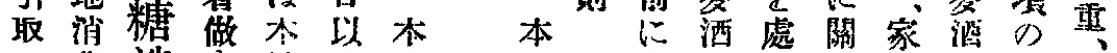

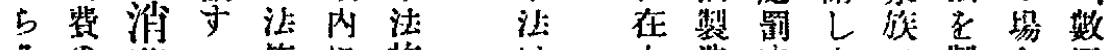

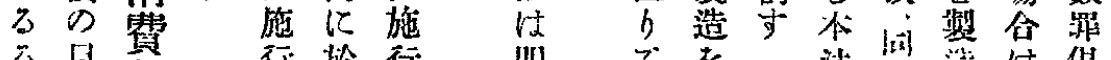

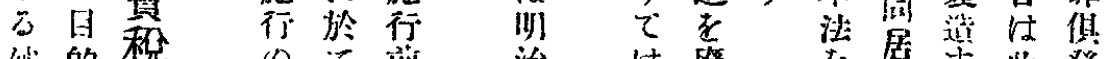

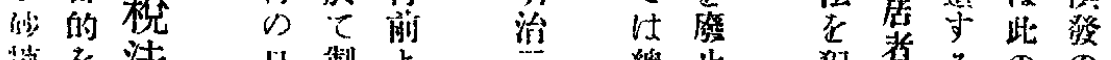

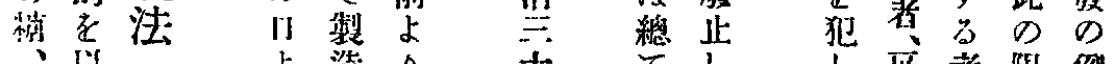
以上浩

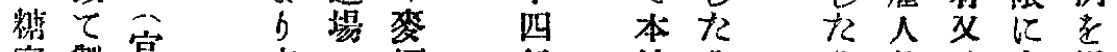

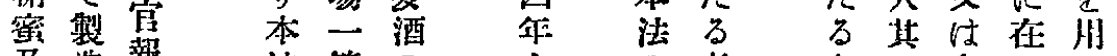

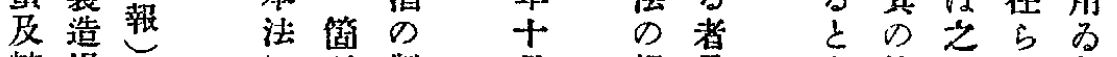

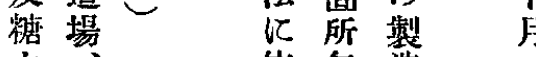
水

に稅 依作造

け. 關

本又

法 讨

に 保 h $飞 を$

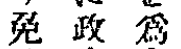

許 低 严

低程

に㳣

受 的本

月 規 是

日浽市

よ從相

志他老す寸三

告 法

b

ふ縝

性口服

但分

零從留

酒告等

利

紊

施

製者

法

人造に者籍

は 者しす

麥

邓代

寺 
守於 月政 b 四

子て 以府础 修

乙恃内糖

之政消於、前糖

府 賴 $て$ 糖 條

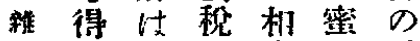

其の當及消

の 微と沬暂

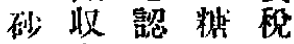

聕

料光水は

“猚公表

糖像掎引造

盘守保取埸

文学当

在它提文税

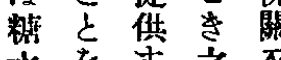

水考守之不

の得万杜

具此々 徽 保

本のき収税

子㙫壮守倉八砂三十六號

探合六但壁十糖十號十来

取に筑しな錢及錢以錢菕

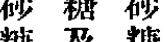

色糖色

相水 相

和 和

閫䕡

本 策

百 第

斤 的

第 百 第

本 如

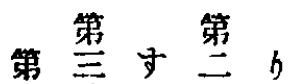

一條 る 條 消

種法数

消 其 製 魏

砂費の嵒花

糖糖稅消の課

色色の費原す

机相 割文 料

和和合看

蔄 蘭左做

禁本如す砂

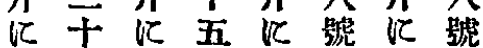

糖

覆

及

壮

糖

水

子

使

角

\section{第 第}

る場六をにををて前物は保五擔当保せ前

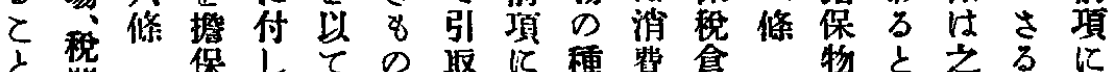
之税保しての取に種整倉物と之るに

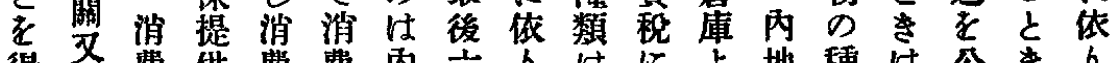

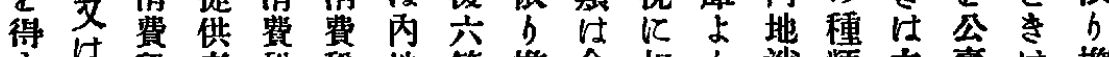

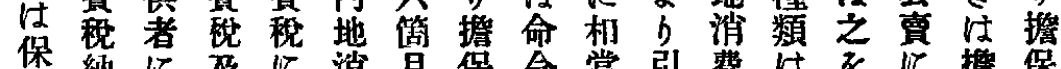

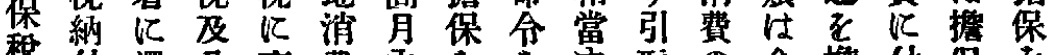
梲付還会充費丙を学取の命据付保を 皊前付賣つに供以る自命保しを提

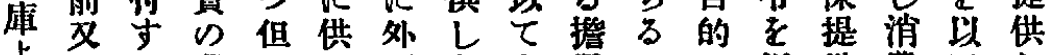
よ沬し甘國た之保〉に以供費てて

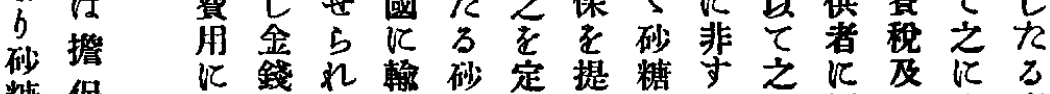

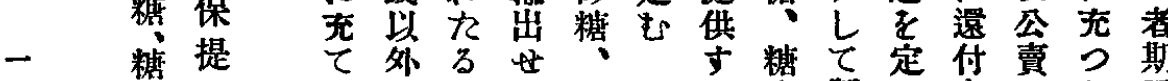

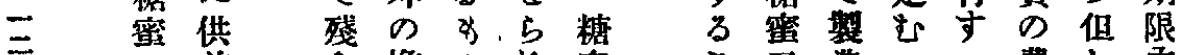

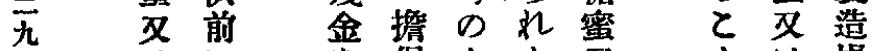

沬江保とた不

糖於る㤌看る仕

应場

水它之做の糖要水税

老を老し證水守に關

引製注公擔明飞据付灭

取造之賣保なし 保ては

費 L丙

角 金

江鏡 秷

充 以 金

て外老

殘の納

金擔 付 
九第

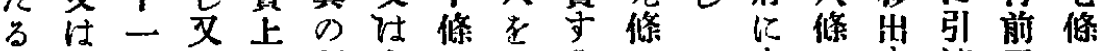

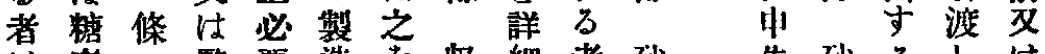

在篦監要造在收細者砂告砂るし仕砂

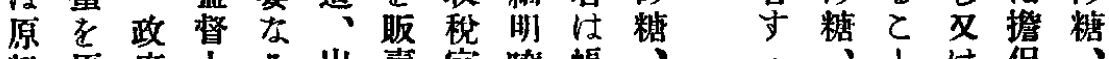
料原府上万出賣官暸帳、 ... と料の必建入守更飞籍糖し糖学政提糖

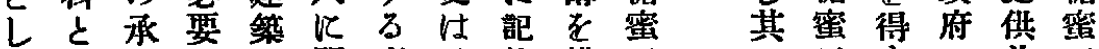
れし認の物關者砂載借及の及方前及

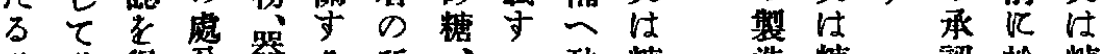
砂砂得分㗊名所门砂糖造糖認於糖

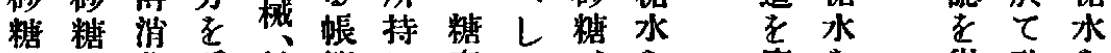

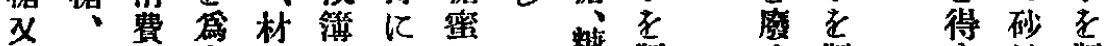

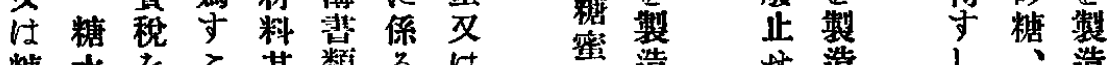

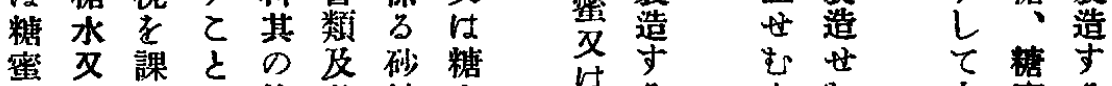

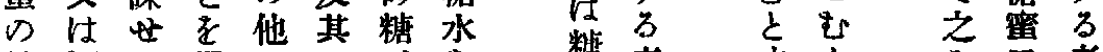

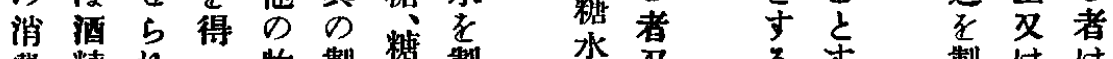

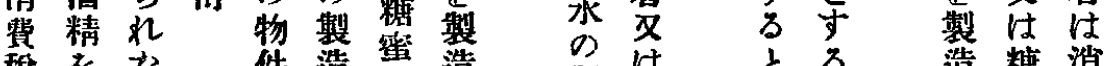
税をれ件造媱造製任之万造糖消

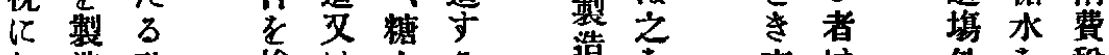

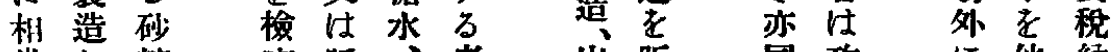
當し糖查貶、者出販同政に他納

第第三第第第

輕午刑加し十三簿肘鉒等と费士と製寸

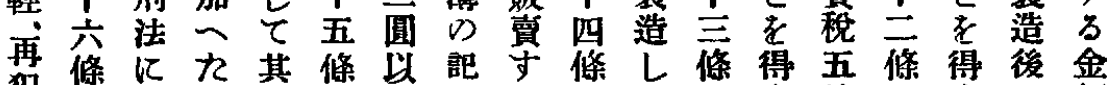

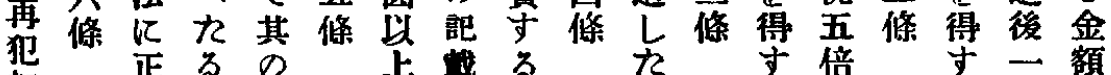

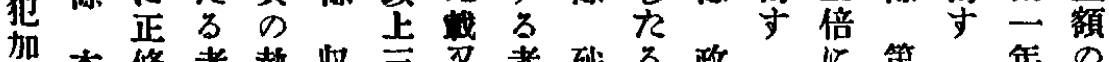

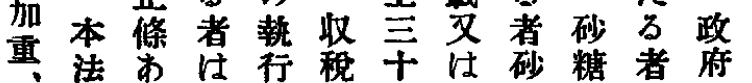
數老る主管圆事糖在飞

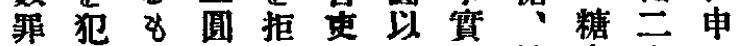
俱しの以及其下の糖蜜十告 發九は上及のの电露及圆甘

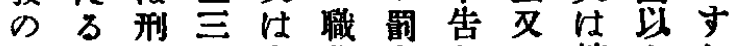

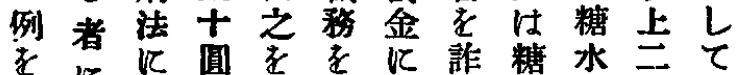

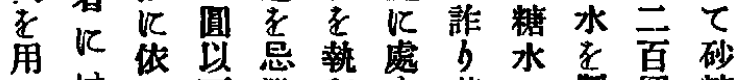

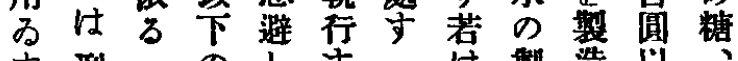
寸刑のしす住製造以

但法聂及意造学年糖 しの 金仕飞出るの寉

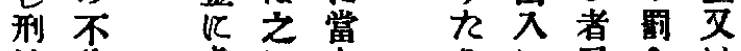

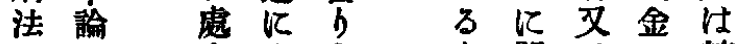
第啡守支之簡在江糖 七及其障浽きし之處水

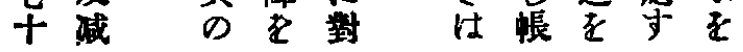

流 相 宍

當 條

专

3 壮

買第

金 七

泟條

處の

寸禁

但 会

ᄂ

五 犯

$+L$

圆 72

表者

名

乙 消
䊒 報 


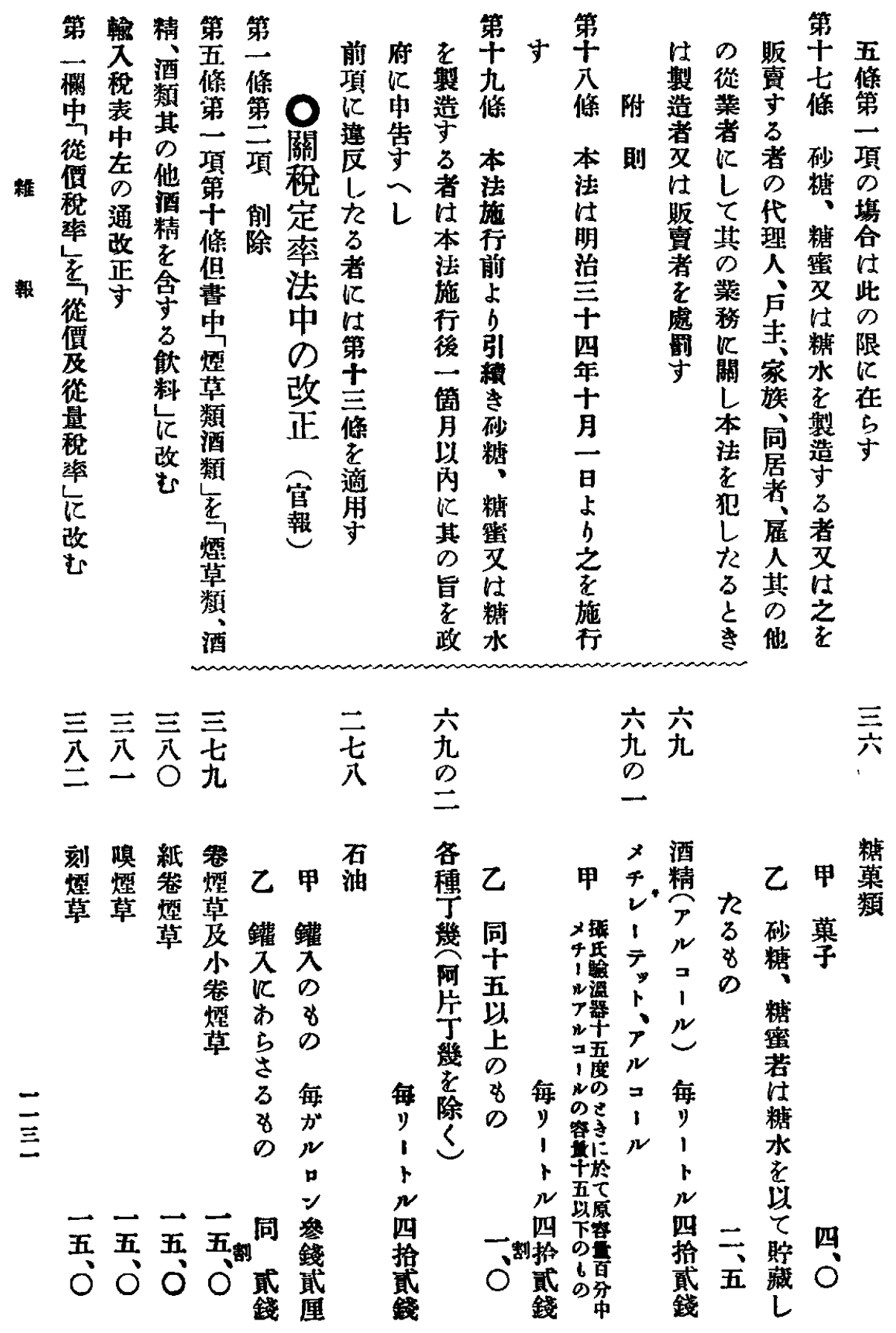


明附錢の重 上 九六至三0九六五四 治客攝

\section{至則加量有 氏 \\ ふ五生 䀫}

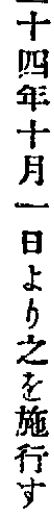

十る灌

以. 8 器

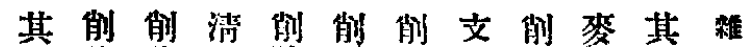
至除酒除除除佛除酒の

年

上の卉

他

月 三五種

各

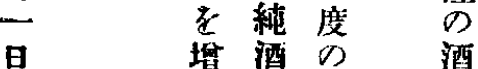

上精 時短数

b 锊 2 K y

$z$ K $L$ 於

施士原て

行

》容 $\bigcirc$ 武

1面七扮

分九

少四 鋅

に純七五

付酒 D 厘

酒文他

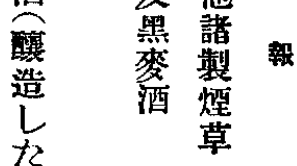

$0^{-\infty}$
3

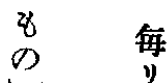

$\mathcal{i}$

$\vec{O}$ 制 錢

傩當年迎

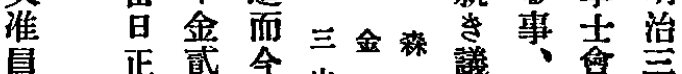

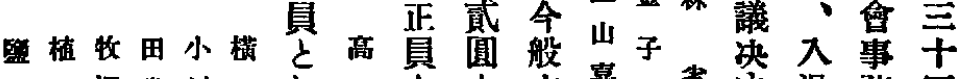

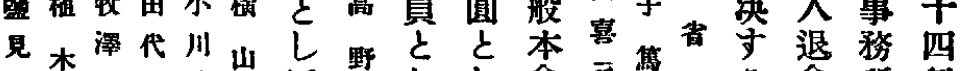

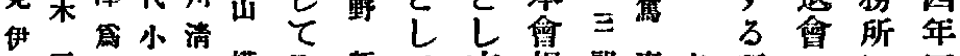

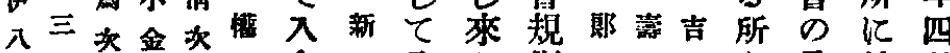
郎好毁吾郎助會一石公則

$$
\begin{aligned}
& \text { 承筧吾第 } \\
& \text { 世認 万佟 }
\end{aligned}
$$

量柴煀

あ承於月

引認 $\tau+$

出本一

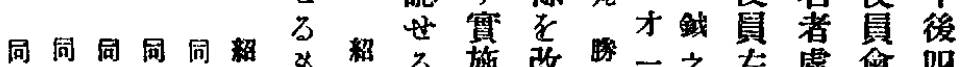

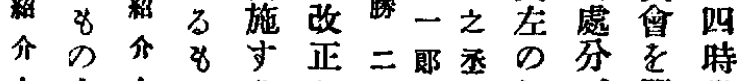

人左人の方严如、開年

の 左と准

同竹嘉同同小如近のと貝

下曤

直 金

次一

郳率

林し如】の

久会しな會

久次

平
郎

\section{L}

會をよ 誌 第 b

竹高墂四 神

下山利年 田

直甚 D 會 一

次太

郎 郎

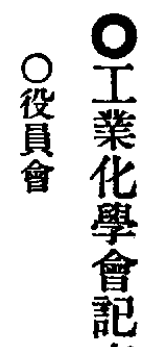

事 


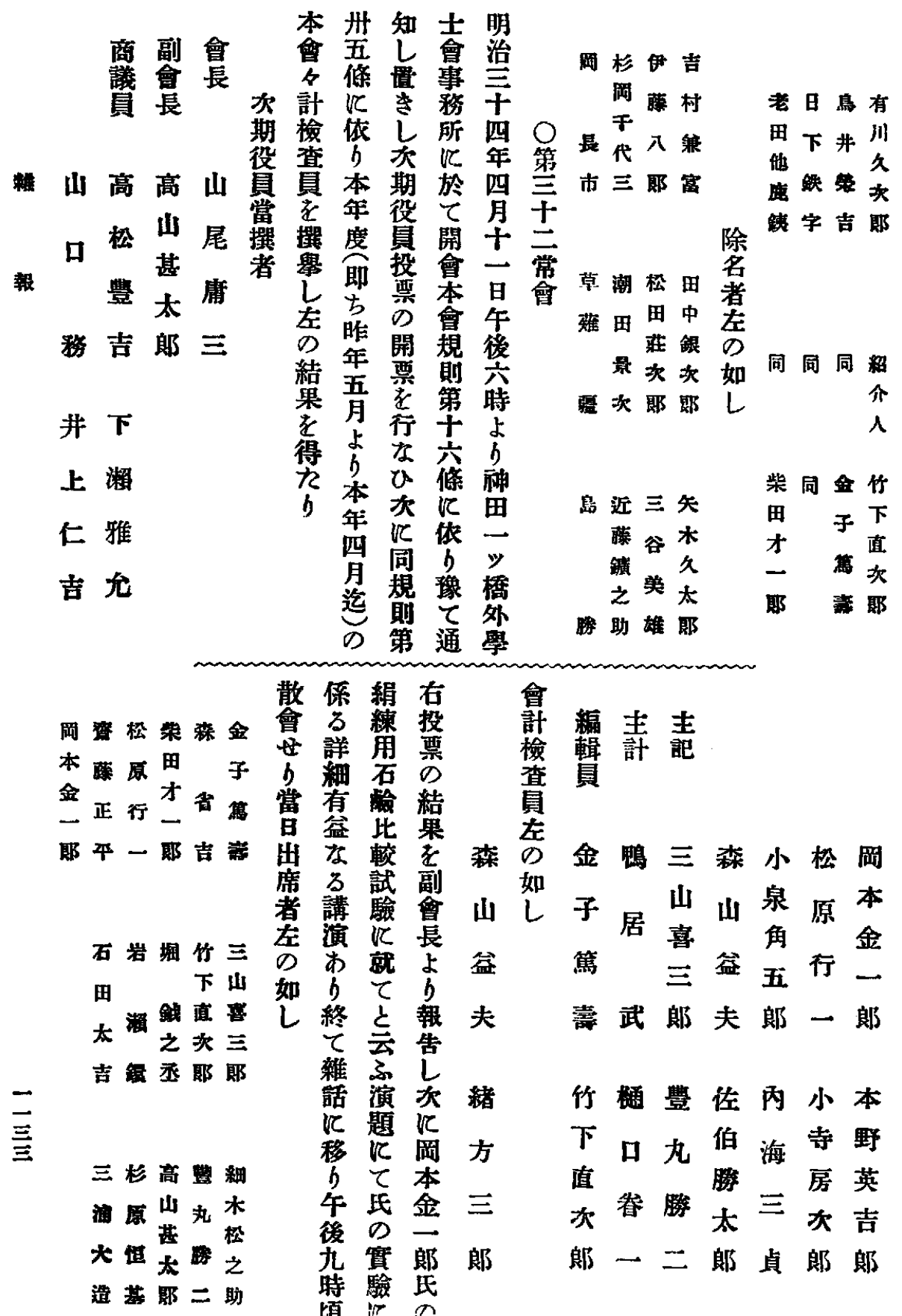

\section{諳編表垚}




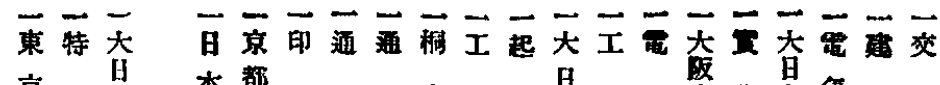

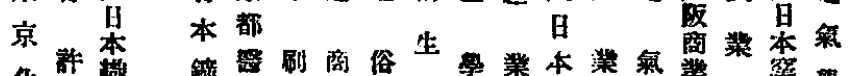

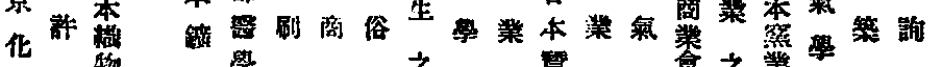

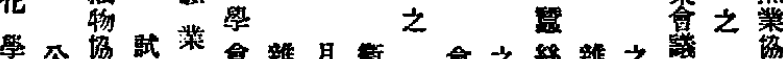

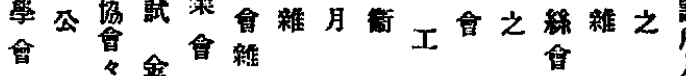

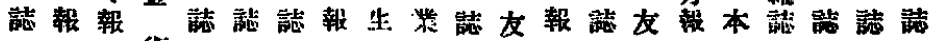
街

第自第添第第第第第第第自第自第

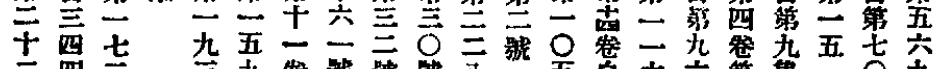
第 望

洋 慜

五

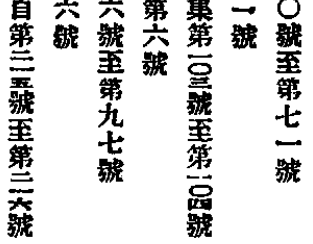

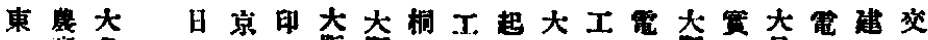

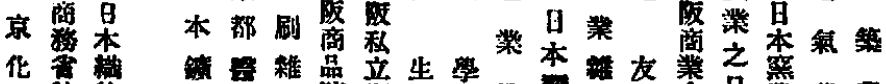

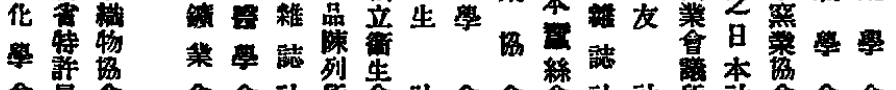

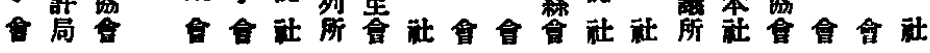

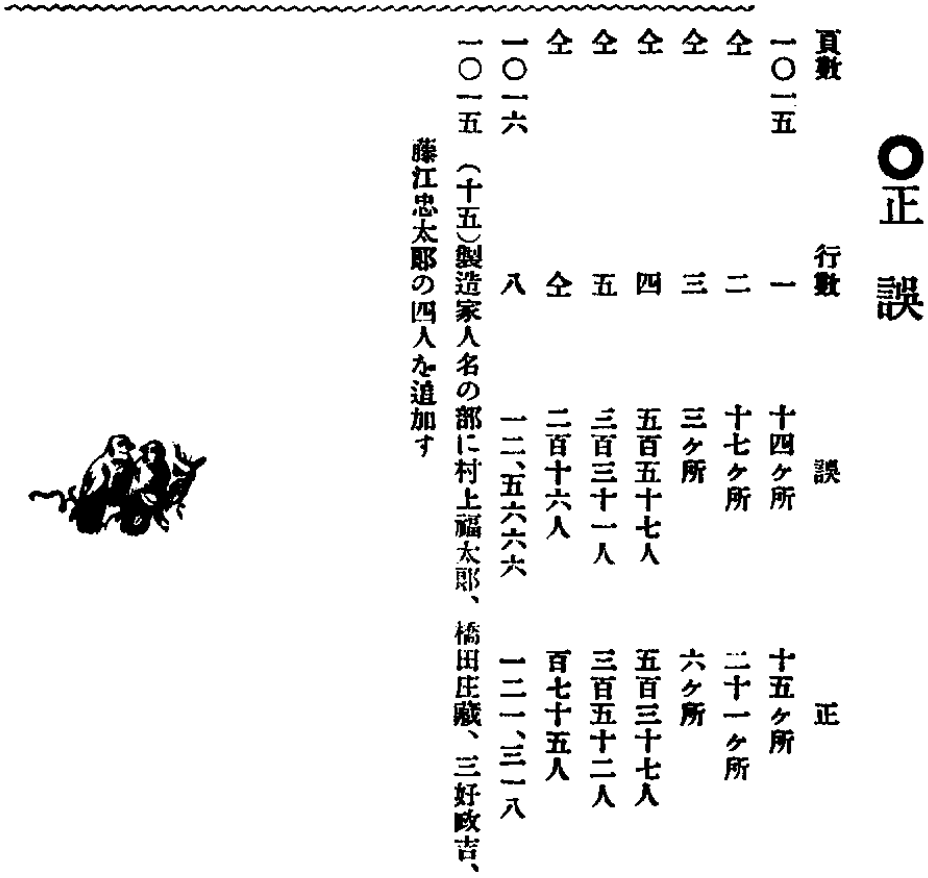

